Journal of Natural History, 1988, 22, 1301-1324

\title{
Re-establishment of the Family Eumedonidae Dana, 1853 (Crustacea: Brachyura)
}

\author{
ZDRAVKO ŠTEVČIĆ \\ Rudjer Bošković Institute, 52210 Rovinj, Yugoslavia \\ PETER CASTRO \\ Biological Sciences Department, California State Polytechnic University, \\ Pomona, California 91768-4032, U.S.A. \\ ROBERT H. GORE \\ 288-2 Winner Circle, Naples, Florida 33942, U.S.A.
}

(Accepted 30 October 1987)

On the basis of a re-examination of all available data concerning the systematic position and status of the genus Eumedonus and allied genera it is concluded that these taxa form a separate family within the superfamily Xanthoidea (sensu Guinot, 1978). The family is characterized not only by particular morphological features but by the symbiotic mode of life of its members.

KeYwords: Eumedonidae, Revision, Brachyura, Symbiosis.

\section{Introduction}

The subject of the present revision is a small group of brachyuran crabs variously classified as the subfamily Eumedoninae of either the families Parthenopidae or Pilumnidae, as a separate family, the Eumedonidae, or even as the superfamily Eumedonoidea. We address the problem of whether the earlier classification is correct, and suggest changes on the basis of new knowledge. This revision focuses on the alleged relationships of the eumedonine crabs with the parthenopids or with the pilumnids as a key to the solution of the problem. Accordingly, each of these taxa is critically compared. This comparison includes all criteria used by previous authors as well as newer criteria given by Guinot $(1978,1979)$.

\section{Historical review}

The first eumedonine crab to be described was Eumedonus niger H. Milne Edwards (1834) which was included in the tribe 'Parthénopiens'. Dana (1853) subsequently included this genus, together with the genera Ceratocarcinus White, Harrovia Adams and White, and Gonatonotus White in his newly described family Eumedonidae, placing it in the legion 'Parthenopinea' or Maioidea 'Cancridica'. Neumann (1878), however, relegated these genera to the subfamily Eumedoninae, included within the family Parthenopidae. Miers $(1879 \mathrm{~b}, 1886)$ followed this classification. Ortmann

* $(1893,1894)$, however, concluded that these genera required a familial rank and so resurrected the family Eumedonidae. Nevertheless, all subsequent authors, including Alcock (1895), Klunzinger (1906), Borradaile (1907), Rathbun (1910, 1925), Flipse 
(1930), Gordon (1934), Stephensen (1945), Balss (1957), Serène et al. (1958) [in a revision of the group], Serène (1968), Serène and Romimohtarto (1963), Glaessner (1969), Sakai (1965, 1976), and Takeda (1973), continued to consider eumedonines as a subfamily of the Parthenopidae. An exception is Estampador $(1937,1959)$, who listed them again as a separate family. Tirmizi and Serène (1971), however, suggested that the eumedonines belong to the Xanthidae, and $\mathrm{Ng}$ (1938), in his revision of the pilumnid crabs included the Eumedoninae in the Pilumnidae (see also $\mathrm{Ng}$ and Rodríguez, 1986). Guinot (1978) considered the relationships of the group as an open question but later lists them as the superfamily Eumedonoidea (Guinot, 1985).

In addition, the genera Calmania Laurie and Dentoxanthus Stephensen have been included in the Eumedoninae. Although Calmania prima was described by Laurie (1906) and placed in the Xanthidae, authors such as Balss $(1922,1957)$ and Gordon (1934) placed it in the Eumedoninae. Dentoxanthus was described from a single female and included in the Xanthidae but in an uncertain subfamily (Stephensen, 1945). Balss, in his comment by letter (see Stephensen, 1945, p. 163-164), pointed out the unique characteristics as well as the difficulties in the classification of this genus. Thereafter, Holthuis (see Serène et al., 1958, p. 139) drew attention to some 'eumedonine' characteristics in the genus. Another female specimen was later described by Tirmizi and Serène (1971) and thereafter two male specimens by Tirmizi and Kazmi (1982). The latter authors included Dentoxanthus in the Eumedoninae and considered it to be close to the genus Harrovia.

A re-examination of the literature on the eumedonines shows that most of the published information is confined primarily to descriptions of genera and species and that the discussion of their systematic positions and relationships are scant. Some useful information on their morphology has been given by Gordon (1934), Serène et al. (1958), Guinot (1964), Serène and Rominohtarto (1963), Sakai (1976), and Tirmzi and Kazmi (1982). Until recently (Castro, 1978; Van Dover et al., 1986) the larvae for any eumedonine genus was unknown.

\section{Relationships to the Family Parthenopidae}

Eumedonines share with the parthenopids several morphological characteristics. Common features include:

1. The body shape is of an 'oxyrhynchous' type. The anterolateral margins of the carapace converge and the front usually projects into a pseudorostrum.

2. The orbits are small, circular, and well defined, with the inner orbital hiatus filled by the basal antennal article and, in some genera, also with the following article.

3. The eyestalks are usually short and thick and can be retracted into the orbits.

4. The antennules are more or less obliquely folded in antennular fossae.

5. The antennae are not fused with the front or the epistome. The first antennal article (urinal) is very small and in contact with the epistome; the basal (second $=2+3$ ) is the largest, whereas the following articles are more slender. The flagellum is slender and short.

6. The epistome is short, wide, not overlapped by the third maxillipeds, and produced forward in the middle.

7. The buccal cavern is usually quadrangular and completely covered by the third maxillipeds. The palp of the latter is articulated at the anterointernal angle of the merus.

8. The chelipeds are not pressed tightly against the anterolateral margin of the 
carapace and are rarely asymmetrical. They may be extended laterally or held transversely in front of the carapace. The fingers are much shorter than the palm and curved abruptly on the hand at an angle toward the side of the fixed finger at its dactylo-propodal articulation. The ischio-meral articulation is fused, but it has a distinct suture.

9. The sternum is of moderate breadth, with sternites arranged more or less in parallel, except the last one, which is arranged radially. The sterno-abdominal cavity is present and the retaining system of the abdomen is functional. The median line is present only on one or two (last and penultimate) of the posterior sternites. The posterior part of the thoracic sternum is slightly elevated and rounded, so that the coxae of the fifth pereopods are visible from above.

10. The genital openings are coxal in males, sternal in females; the oviduct opening belongs to the concave type.

11. The first and second proximal abdominal segments are visible from above.

12. The surface of the body is never hairy (or only sparsely setose).

The morphological differences between the two groups are several. These include:

1. In eumedonines the regions of the dorsal surface of the carapace are only partially recognizable (particularly the cardiac and gastric regions), whereas in parthenopids a depression separates the branchial region from the gastric and cardiac regions. In the eumedonines (except Rhabdonotus A. Milne Edwards) the anterolateral and posterolateral margins of the carapace are clearly separated, usually by a spine or at least a well-marked angle. This is similar to that seen in some parthenopid genera (Leiolambrus A. Milne Edwards and Heterocrypta Stimpson).

2. The projecting front, a pseudorostrum, is present in both groups, but in parthenopids it is never notched, although it may be either sharply or bluntly pointed or even obscurely trilobed. In the eumedonines the middle of the front is notched so that it is bilobed or four-lobed in some genera, and only rarely emarginated at the tip.

3. The antennules are folded only slightly obliquely in parthenopids, whereas in eumedonines they are usually more obliquely folded in antennular cavities.

4. The basal (second $=2+3$ ) antennal article usually does not reach the inner orbital margin in parthenopids; in eumedonines it reaches the inner margin and partially fills the orbital hiatus.

5. The buccal frame of eumedonines does not have any specialized features. In burying parthenopids it is sometimes slightly narrowed in front. The palp of the third maxillipeds is well developed in eumedonines, but is somewhat reduced in size in some parthenopids, where it lies more or less concealed in a groove in the merus. This groove is absent in eumedonines.

6. The chelipeds of parthenopids are disproportionately large and long in relation to the body, and characteristically extend transversely in a resting position. The chelipeds of eumedonines are of moderate size and length in relation to the cephalothorax (being relatively larger only in Harrovia) and when inactive they are folded beneath the anterolateral margins of the carapace. The chelipeds of parthenopids are usually triangular in cross section (with the exception of Daldorfia Rathbun); in eumedonines they are cylindrical in cross section. The tips of the chelae are usually directed downward in parthenopids, a situation not observed in live eumedonines. 
7. The sternum is at level III B (following the terminology of Guinot, 1979) in eumedonines, whereas in parthenopids it is at level III C, that is, characterized by having all sternal sutures interrupted. The only exceptions are Daldorfia Rathbun and Thyrolambrus Rathbun, where the sternum is also at level III B (4/5 and 5/6 sternal sutures interrupted and 6/7 and 7/8 complete). The median line is complete in eumedonines, but it is incomplete or vestigial in parthenopids.

8. The abdomen is divided into seven freely articulating segments in both sexes in eumedonines; segments 3 to 5 are always fused in parthenopid males, but sutures may or may not be visible.

9. The male first pleopods of parthenopids are usually long, cylindrical, stout, more or less tapering and/or bent at the tip, sometimes bluntly truncated, and usually armed with spines, spinules, and setae. In eumedonines they belong to the Pilumnus-type: long, slender, and S-shaped. Its distal portion is armed with rows of bristles and the tip is obliquely curved downward and outward. The male second pleopod of parthenopids is relatively long and usually shorter than the first. Its corneous tip is spiral, elongated, and usually recurved distally. In eumedonines the gonopod tip is very minute and sigmoid; its distal end is somewhat enlarged and oblique and it is proximally armed with small spines.

10. In contrast to parthenopids, which have unspecialized pereopods, the legs of eumedonines have a very flexible dactylus, the result of a modified dactylopropodal articulation. It can be flexed to touch the propodus, thus resulting in prehensile legs. In Zebrida White the dactyli are subchelate. In other eumedonine genera the inner border of the propodus and dactylus is often provided with hairs and spinules. These represent adaptations facilitating attachment to the host.

\section{Relationships to the Family Pilumnidae (sensu Guinot, 1978)}

Morphological similarities between the eumedonine genera Ceratocarcinus White and Harrovia Adams and White (Group B of Gordon, 1934) when compared with a typical representative of the Pilumnidae (e.g. Pilumnus spinifer H. Milne Edwards) are of interest. The similarities between the male first pleopods of eumedonines and those of the Pilumnidae are especially intriguing. Furthermore, the larvae of the eumedonine, Echinoecus pentagonus (A. Milne Edwards), also show affinities with the Pilumnidae (see below). These similarities (and exceptions) between the Pilumnidae and the remaining eumedonine genera (Group A of Gordon, 1934) are given as follows:

1. Cephalothorax a little broader than long. Anterolateral margins of the carapace are usually shorter than the posterolateral margins. The regions of the carapace are usually only partially defined, but may be distinct in some species.

2. The frontal margin of the carapace is broad and (except in Group A) exceeds by half or greater the maximal carapace length. The margin is lamellate and deflexed in some species.

3. A median notch is present, and the two lateral notches in which antennal flagella are usually placed (except in Group A) result in a four-lobed structure.

4. The inner suborbital angle is often prominent (except in Group A).

5. The chelipeds are not pressed tightly against the anterolateral margin of the carapace, but may be folded against or beneath the buccal cavity when in resting position. 
6. The ischio-meral articulation of the chelipeds is fused, but the suture is wellmarked.

7. The fingers of the chelipeds of all pilumnids and of some species of Harrovia are dark.

8. The buccal cavity is quadrangular; the epistome is short, wide, and produced forward medially; the endostome bears a longitudinal ridge.

9. A sterno-abdominal cavity is present, as is a functional locking system of the abdomen.

10. The abdominal segments are not fused, abdominal plates cover the entire space between the coxae of the fifth pereopod.

11. The male first pleopods are very slender, long, and sinous; the second is very small and sigmoid.

12. The sternum is at level III B (following the terminology of Guinot, 1979).

13. The ventral portion of the cephalothorax is rounded posteriorly, so that the coxae of the last pair of pereopods are elevated and visible from above, as are the two proximal abdominal segments.

The differences between pilumnids and eumedonines are as follows:

1. In eumedonines the carapace is subhexagonal or subpentagonal, but in pilumnids is transversely oval or subquadrilateral. The cephalothorax is more flattened in eumedonines.

2. The anterolateral carapace margins of pilumn:ds are arcuate and dentate (usually with at least three prominent teeth behind the postocular angle). In eumedonines the margin is usually straight or even concave (as in Echinoecus Rathbun) and with (e.g. Harrovia) or without spines, but with one to three lobes and a very distinct spine at the junction of the anterolateral and posterolateral margins (except Rhabdonotus A. Milne Edwards).

3. In pilumnids the surface of the carapace is usually granular, spinose, or hairy, whereas in eumedonines it is smooth and rarely with spines on the dorsal surface.

4. The antennules fold obliquely in eumedonines, transversely in pilumnids.

5. The basal antennal article $(2+3)$ may fill the suborbital hiatus in some eumedonines, but in pilumnids it is almost always much larger and not only fills the suborbital hiatus but may just reach the frontal margin as well.

6. The orbits of pilumnids are elliptical and of moderate size; those of eumedonines are small and subcircular. The eyestalks are of moderate size in pilumnids, but short and thick in eumedonines.

7. In eumedonines the chelipeds are equal or subequal in size, not robust and smooth, whereas in pilumnids they are more or less dissimilar, strongly granulated or even spinose, at least partly covered with setae, and robust. In pilumnids the fingers of the chelipeds are directed less obliquely downward than those of eumedonines.

8. The pereopods of eumedonines are often provided with triangular tubercles or even spines, whereas those of pilumnids, if armed, show only reduced spinulation. In addition, eumedonine walking legs are prehensile.

9. The inner ends of the $4 / 5$ and $5 / 6$ sternal sutures are closer in pilumnids than in eumedonines.

10. The male first pleopod of eumedonines is relatively stouter than that of pilumnids. 
11. Eumedonines are small symbiotic crabs (i.e. establishing close, obligate, and often specific association with an invertebrate host as defined by Castro, 1986), often variegated in colour, and much less active than the larger, more uniformly coloured and active pilumnids, almost all of which are free-living.

\section{Larval characters and development in eumedonine, parthenopid, and xanthoid crabs}

The only species of eumedonine crab of which the larval development has been published is Echinoecus pentagonus (A. Milne Edwards) (see Castro, 1978; Van Dover, et al., 1986). Larvae of Harrovia elegans de Man have been reared and described by Y. Fukuda (unpublished). A detailed examination of the larval development and zoeal characters shows that E. pentagonus, at least, is not a parthenopid. Having no more than three (or rarely four) zoeal stages (whereas most parthenopid crabs pass through at least five stages) and exhibiting zoeal features that seem to align $E$. pentagonus more closely with the Xanthoidea (sensu Guinot, 1978) rather than the Parthenopidae, supports this removal. Specifically, the setation of the maxillary endopod, and the maxillulary endopod do not agree with known parthenopid zoeae. General carapace configuration is not parthenopid, but xanthoid, and is nearly identical to the larvae of some pilumnids (e.g. Pilumnus dasypodus Kingsley) in nearly every appendage feature, including positioning and number of setae (see Sandifer, 1974). Additional similarities are seen in pilumnid and E. pentagonus larval telsons and most abdominal somite armature. Indeed, these similarities taken as a whole would make it very difficult to separate the larvae of E. pentagonus from several species of Pilumnus Leach or its relatives.

The observed similarities between E.pentagonus and, for example, P.dasypodus, pose some interesting and vexing questions. If larval characters are conservative, as is traditionally held, then the xanthid features of Echinoecus Rathbun suggest that this genus is non-parthenopid (see Van Dover et al., 1986 for discussion). Until larvae from the type genus of the family (Eumedonus H. Milne Edwards) and other eumedonine genera become known, it is not certain at present whether eumedonine larvae (sensu lato) are a consequence of convergent evolutionary trends, and/or whether the eumedonine and the pilumnid crabs shared a common ancestor. There is no agreement at present as to which larval features are plesiomorphic and which are apomorphic and little further can be said. Examination of more eumedonine larvae would therefore provide much needed additional data.

\section{Ecology}

Eumedonine crabs differ sharply from parthenopids in terms of their respective habitats. Whereas parthenopids are found free-living on various types of substrates (particularly sand, shell hash, and mud), eumedonines appear to live in obligate symbiotic associations with echinoderms and cnidarians. Although in almost all eumedonines the nature of these associations remains unknown, the term symbiosis is used here to encompass all types of close heterospecific associations irrespective of harm or benefit to the partners (see Castro, 1986). Nevertheless, eumedonines are often referred to in the literature as commensals or parasites even when information on their feeding habits and other aspects of the symbiont-host relationship is not known.

Most of the early records in the literature provide little information on the habitats of eumedonines. Many specimens were obtained from dredged material and no records of hosts are given. With the advent of scuba diving, the symbiont-host relationship can be preserved during collection, thus affording more reliable information on microhab- 
itats and host specificity. These crabs, however, easily remain unnoticed as a result of their characteristic small size and cryptic colouration. Table 1 summarizes all recorded hosts from the literature and from specimens examined by P. Castro from several collections.

Echinoderms are by far the most common hosts. Echinoids are the almost exclusive hosts of Echinoecus Rathbun, Eumedonus H. Milne Edwards, Gonatonotus White, Proechinoecus Ward, and Zebrida White, whereas Ceratocarcinus White, Harrovia Adams and White, and Rhabdonotus A. Milne Edwards have almost always been recorded from crinoids. Soft corals have been recorded as additional hosts in two species, and a sceleractinian coral in another.

Information on habitat and/or hosts is scant for eight of the species. Two records of one of these species, Glyptocarcinus truncatus (Rathbun), were found free-living under rocks by scuba divers at depths of 21 and $23 \mathrm{~m}$ from the island of Oahu, Hawaii (see Takeda, 1979). A closely related species has been recorded in Japan from a 'coral fishing net' (Takeda, 1973) and from a lobster net (as Harrovia truncata, Sakai, 1976). A young female of Harrovia elegans de Man was collected 'on the surface of rock in intertidal zone' in central Japan (Imanaka et al., 1984).

Eumedonines have been recorded only from the Indo-west Pacific region (see Table 1). Ceratocarcinus dilatatus A. Milne Edwards, however, has been reported from South Australia (Hale, 1927; Griffin and Yaldwin, 1968). Eumedonines range from the intertidal zone (as in Proechinoecus sculptus Ward) to a depth of $426 \mathrm{~m}$, the maximum depth recorded for Glyptocarcinus truncatus (Rathbun) (see Rathbun, 1906). Echinoecus pentagonus (A. Milne Edwards) appears to be the most widely distributed species.

Eumedonines are characterized by walking legs provided with a highly flexible dactylo-propodal articulation, an adaptation which provides them with a prehensile mechanism for clinging to the host. A subchelate positioning of the dactylus against a distally enlarged merus (as in Zebrida) and the presence of hairs or spinules along the merus and dactylus are of similar adaptive significance. Similar morphological adaptations are observed among symbiotic xanthid crabs (Serène, 1961).

Locomotion of eumedonines on sandy or muddy substrates is difficult or impossible, as has been observed for Z.adamsi White (Suzuki and Takeda, 1974), E.pentagonus (P. Castro, personal observation), and C.longimanus White and H. albolineata Adams and White (P. Ng and G. Lim, personal communication). The cryptic colouration and spinulation of the carapace in many eumedonines and their small size (carapace length not often exceeding $1.0 \mathrm{~cm}$ ) are additional (although not necessarily exclusive) adaptations for living in close association with a host (see Wicksten, 1983).

Very little is known about the biology of eumedonines. E. pentagonus is the species most widely studied. Males and immature females inhabit the peristome and the test of their sea urchin host, feeding on epithelial tissue and most probably on the tube feet (Castro, 1971). Tissue destroyed by the small crabs is rapidly regenerated by the host. The much larger adult females are confined to the host's rectum, typically inducing the conspicuous, gall-like calcification of the host's periproct. They feed on the host's fecal pellets and on host coelomocytes that accumulate as a pigmented layer on the lumen of the rectum. Z.adamsi was recorded by Mortensen (1943) as feeding on 'spines, tubefeet, and pedicellariae, cleaning the test completely along its way' in Salmacis bicolor L. Agassiz, a sea urchin from the Gulf of Thailand (also see Rathbun, 1910). The crab is similarly described by Suzuki and Takeda (1974) as responsible for creating 


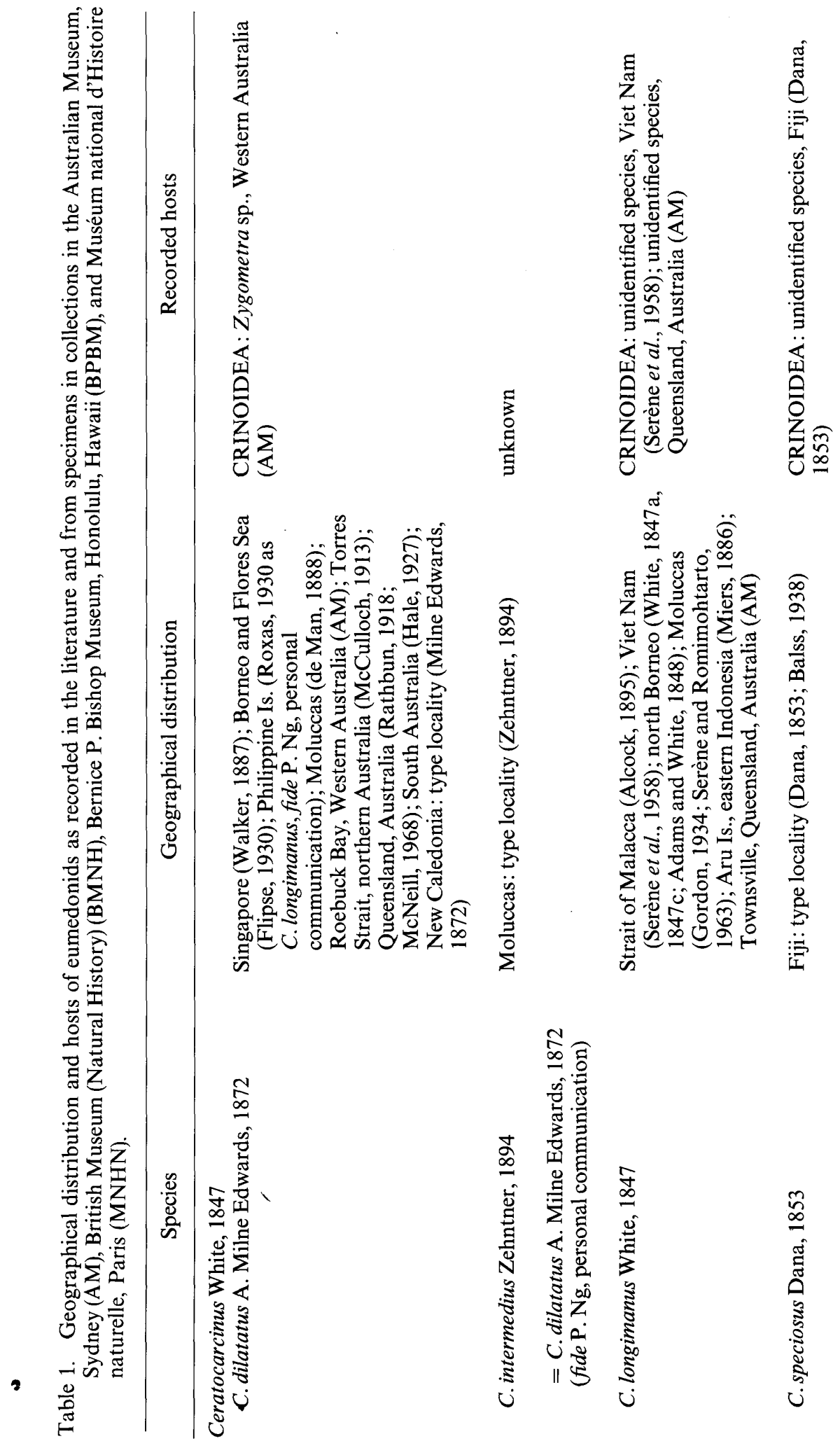




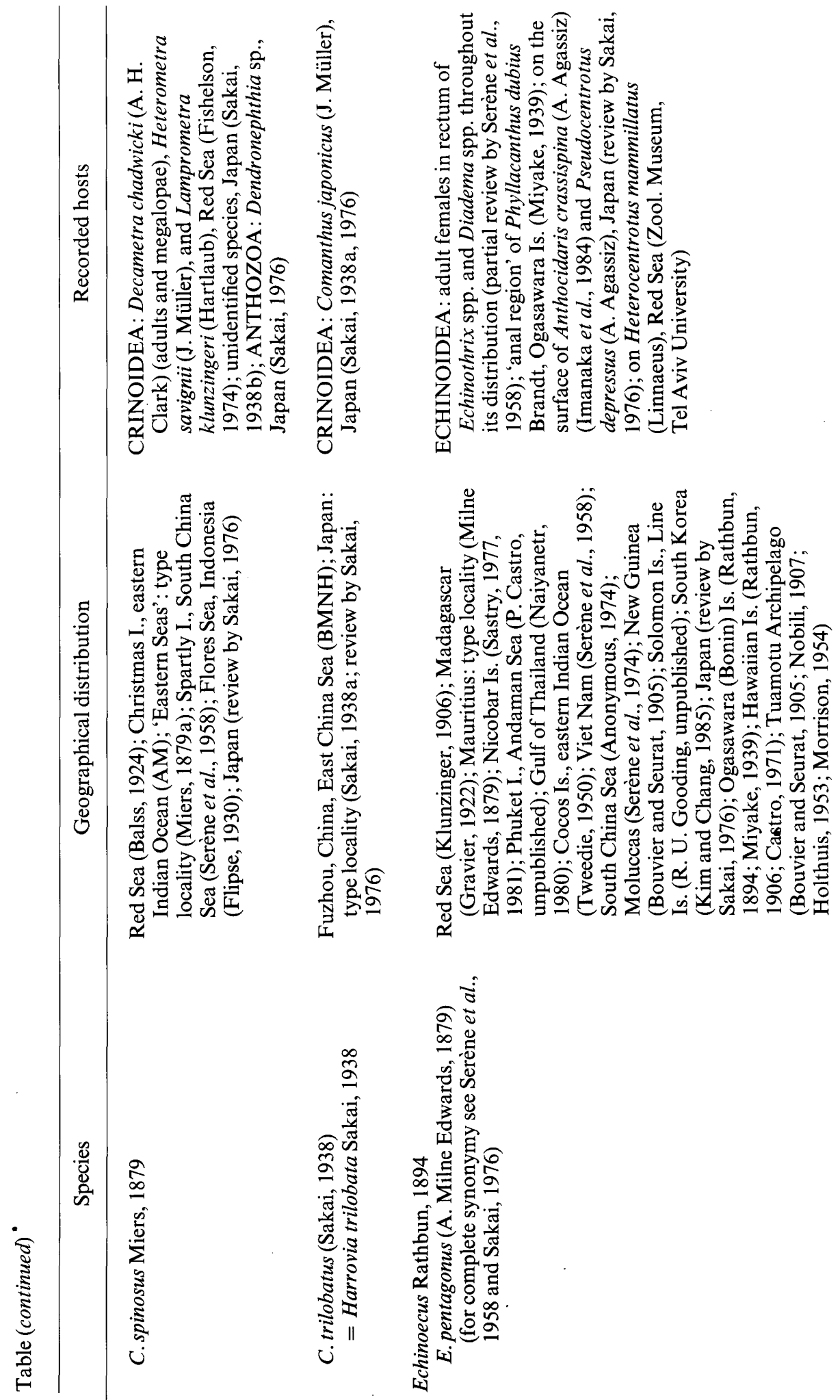




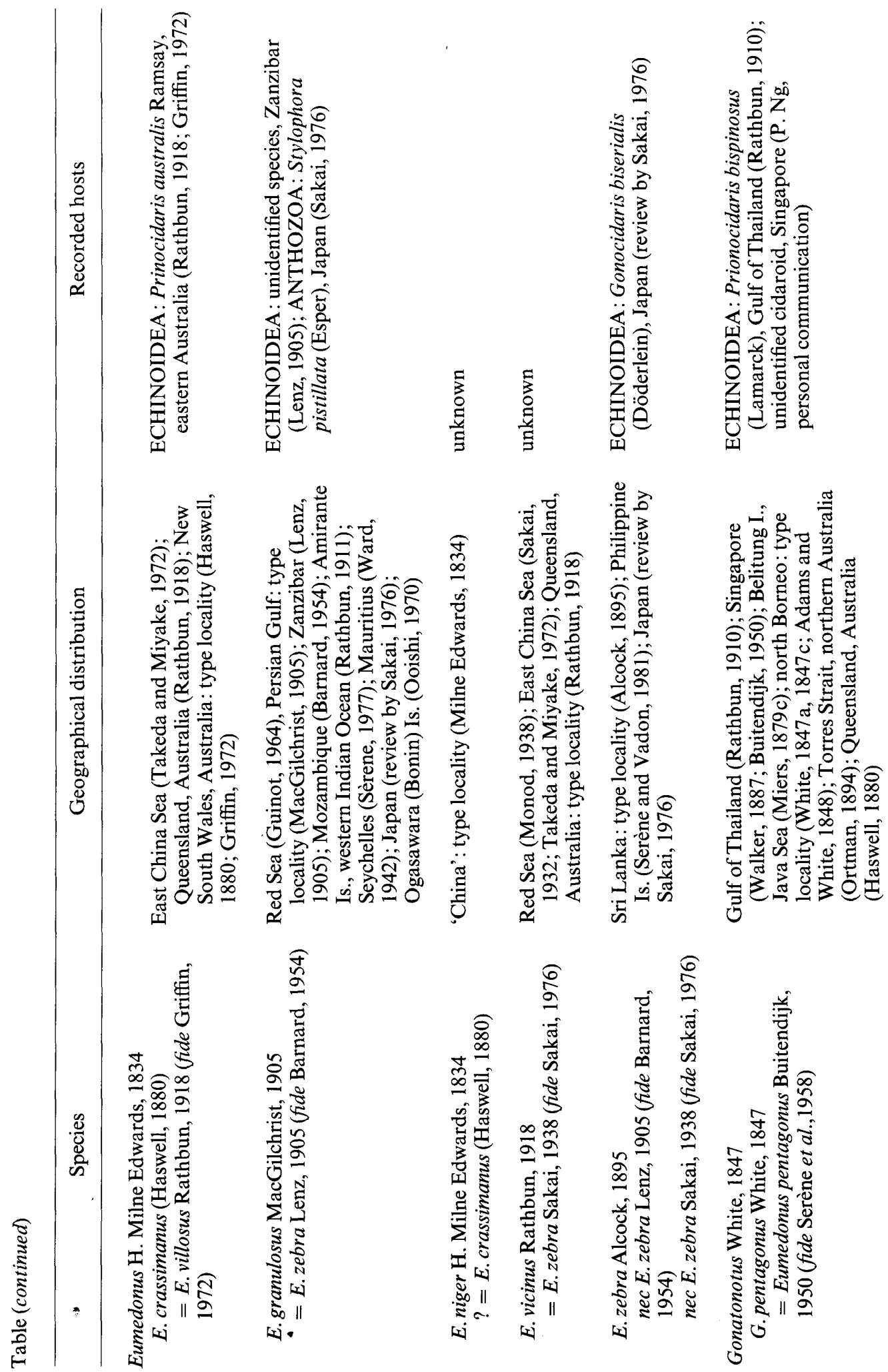




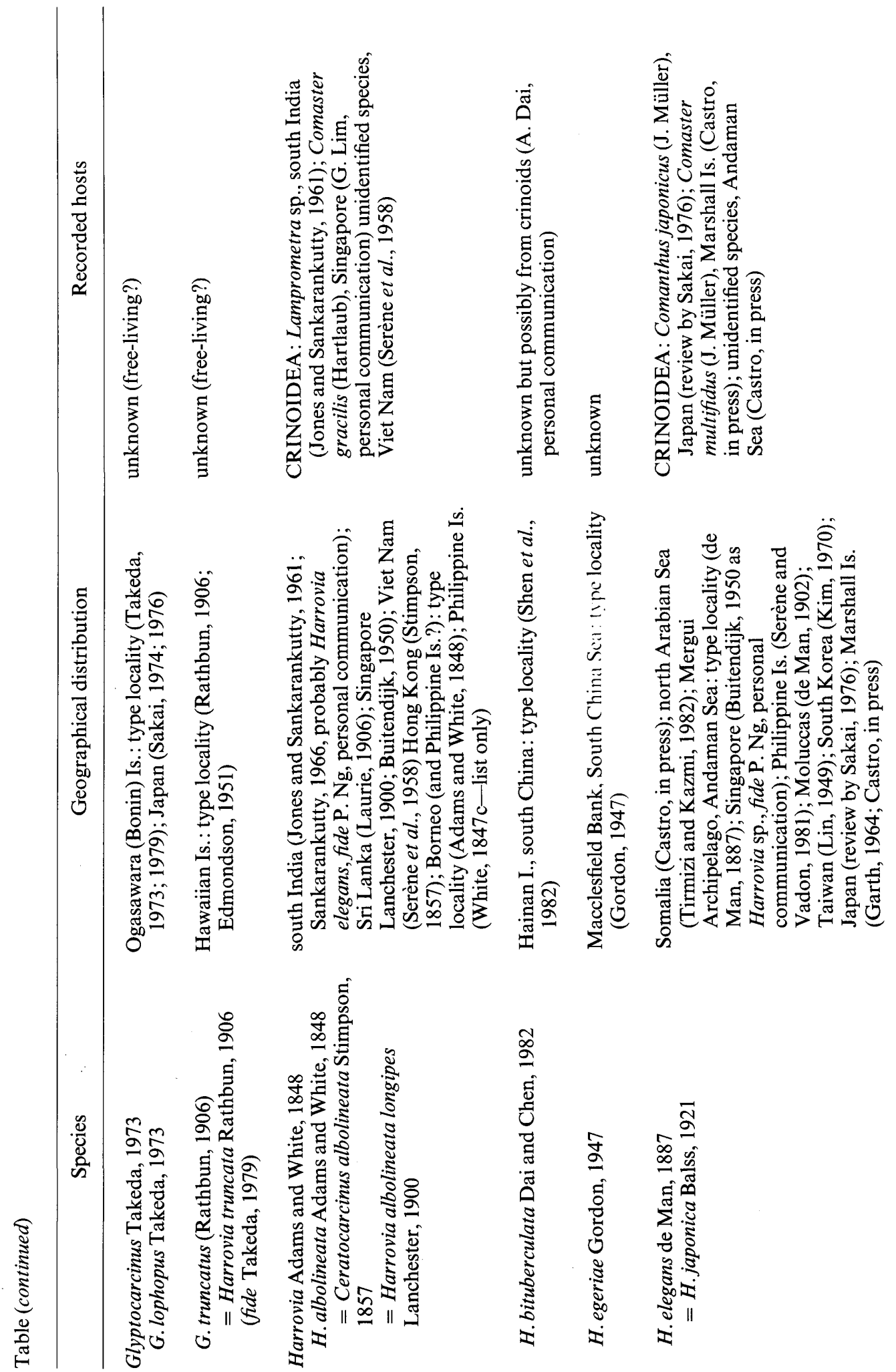




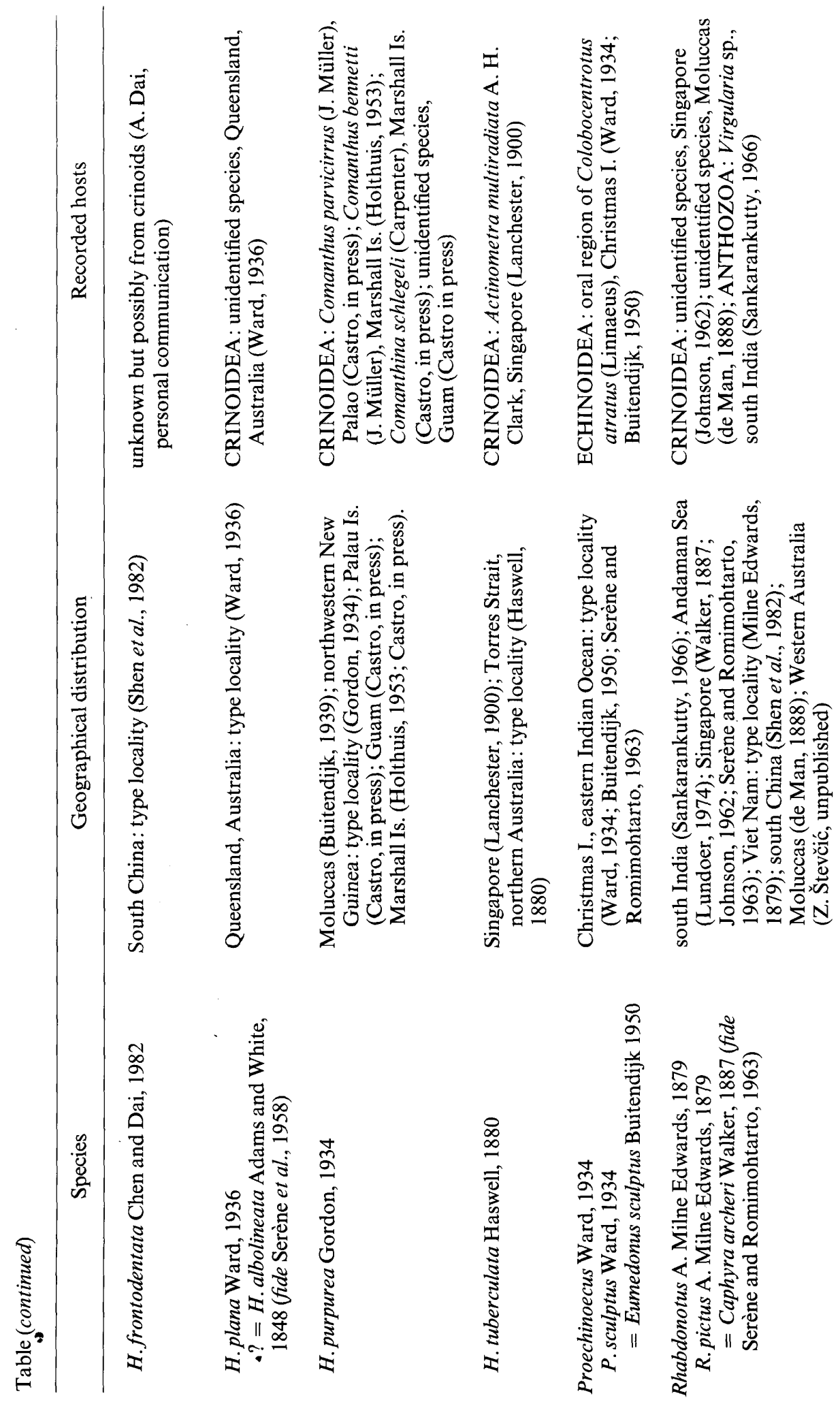




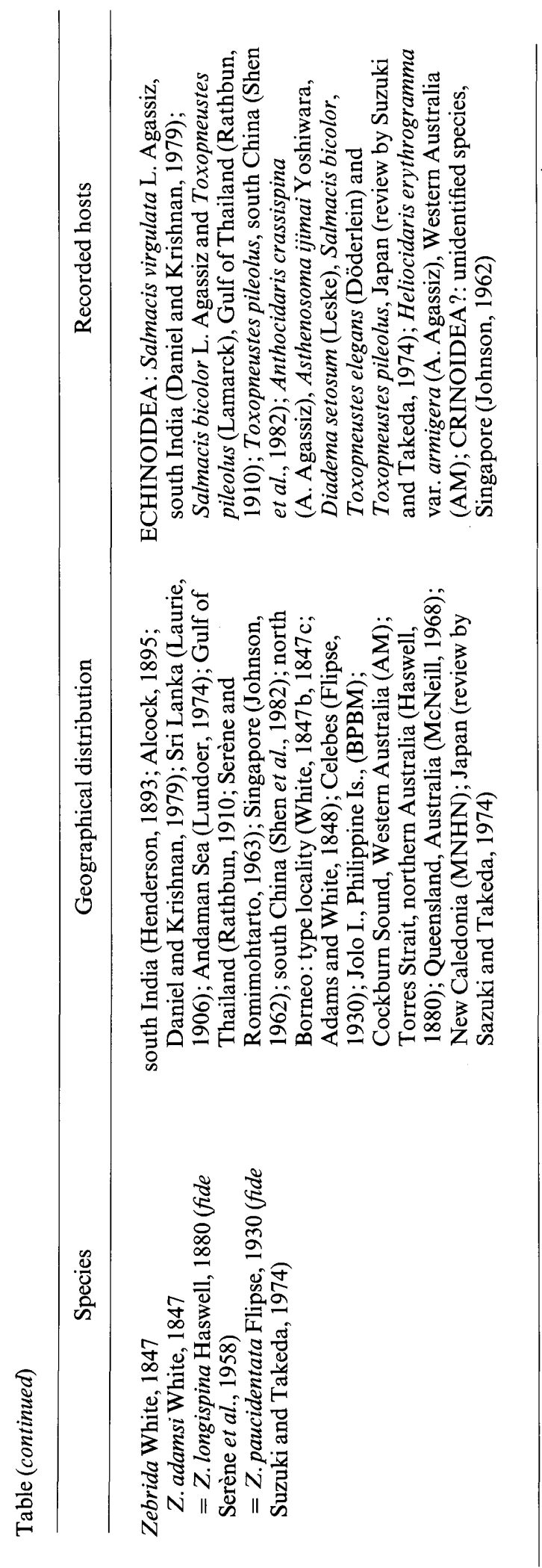


small areas devoid of spines on the test of sea urchins in Japan; Daniel and Krishnan (1979) report it as causing damage to the base of the spines of its echinoid host in south India.

Larval settlement and host selection behaviour in laboratory-reared megalopae of E. pentagonus were analyzed by Castro (1978). Results suggest that the megalopae are actively involved in host selection and that metamorphosis into juveniles is triggered by contact with material from live hosts. In south-central Japan, immature males and females can be found only on the test of sea urchins. This is apparently the result of larvae that are carried by warm currents and are able to develop into juvenile crabs but which are subsequently unable to survive winter temperatures.

It is apparent that eumedonines are specialists that have evolved morphological and behavioural adaptations to live as obligate symbionts on the surface of echinoderms and cnidarians. In contrast, parthenopids are free-living, relatively unspecialized omnivores and detritivores (Gore and Scotto, 1979). Hosts provide eumedonines with protection and with food sources that may include epithelial and other types of tissue, detritus caught on the surface of the host, fecal material, and mucus. The occupation of the host's rectum by the adult females of E.pentagonus represents an additional adaptation paralleling those in some pinnotherid crabs which are symbionts of molluscs, echinoderms, and other invertebrates.

\section{Discussion}

An important consideration is whether the eumedonines should be treated as a separate family (see Dana, 1853; Ortmann, 1893, 1894; Estampador, 1937, 1959), a subfamily of the Parthenopidae (as Neumann, 1878 and most subsequent authors), a subfamily of the Pilumnidae (sensu Guinot, 1978) following $\mathrm{Ng}$ (1983), or even as an independent superfamily (Guinot, 1985).

There are some general similarities between eumedonines and parthenopids, but the question remains whether these similarities are a result of convergence or of common ancestry. Some of the similarities are shared only by these two taxa; others are common within several families within the Heterotremata (sensu Guinot, 1978). The latter include (1) the position of the antennules, (2) the shape of the buccal frame and third maxillipeds, (3) structure of the sternum, (4) position of the gonopores, and (5) position of the basal antennal article. However, there are features common to both groups suggesting that parthenopids and eumedonines are related to some degree. This conclusion is based primarily on particular similarities shared only by these two taxa(i.e., synapomorphies). These include (1) general body shape, (2) shape of frontal margins, (3) size and structure of the orbits, and (4) general shape of the chelipeds, especially the claws. Yet even these characters may have been acquired through convergent evolution.

On the other hand there is evidence indicating relationships of the eumedonines to the Xanthoidea (sensu Guinot, 1978) as noted by Tirmizi and Serène (1971) and Ng (1983), who included eumedonine genera in the Pilumnidae (see $\mathrm{Ng}$ and Rodríguez, 1986). Both groups share similarities in the morphology of the orbits, the position and shape of the chelipeds, the position of the basal antennal article, and particularly in the shape of the male gonopods. Moreover, xanthid crabs such as Calmania Laurie (see below) have been placed in the Eumedoninae, whereas eumedonines such as Rhabdonotus A. Milne Edwards have been included in the Xanthidae.

The larval development of eumedonines has been studied only in Echinoecus pentagonus (A. Milne Edwards) (Castro, 1978; Van Dover et al., 1986) and the zoeal 
stages of this species cannot be considered parthenopid at all but instead are definitely xanthoid-like, and specifically pilumnid suggesting that this genus at least may not even be a eumedonid but a member of the Pilumnidae (sensu Guinot, 1978). Studies on the larval development of the genera Gonatonotus, Proechinocus, Zebrida, Ceratocarcinus, etc. and a comparison of their larvae with those of Eumedonus must be undertaken to provide larval evidence for assessing the relationships of these genera.

Apart from any possible phylogenetical relationships of the eumedonines, parthenopids, and pilumnids, it is obvious that these taxa are very different in their key adaptations to specific modes of life. The symbiotic existence of eumedonines contrasts sharply with the burying (not burrow-forming) mode of life of parthenopids and the omnivorous habits of pilumnids. Their morphological differences are coincident with their ecological differences.

One other problem has been the systematic position of several genera formerly included among the eumedonines. The first is Calmania, classified by the author (Laurie, 1906) in the Xanthidae, and accepted therein by Flipse (1930) and Sakai (1939, 1976). Balss (1922) and Gordon (1934), however, included this genus in the Eumedoninae. Calmania shares some characters with the eumedonines, such as the bilobed and projecting pseudorostrum, obliquely inserted antennules, position of the basal antennal article in the inner orbital hiatus, and the morphology of the male gonopods. But differences are also salient and include a noticeably hirsute carapace and pereopods covered with long, silky hairs, a lamellate pseudorostrum, the absence of a junctional point between the anterolateral and posterolateral margins of the carapace, and in the form of the chelipeds. This last feature is of most importance, inasmuch as the chelipeds are one of the prime appendages in contact with the environment. In Calmania the chelae are most distinctive and quite different from any seen among the eumedonines. Moreover, some species of Calmania (e.g. C. simodaensis Sakai) are similar to the Pilumnidae.

A similar problem is the systematic position of Dentoxanthus (Stephensen, 1945). The most common species, D. iranicus Stephensen (a second species, D. komodoensis Serène, needs to be revised), shares some common morphological characters with the eumedonines, as noted by Holthuis (see Serène et al., 1958) and Tirmizi and Kazmi (1982). These authors considered this genus to belong to the Eumedoninae. There are similarities in the rhomboid form of its carapace, the junction between the anterolateral and posterolateral margins of the carapace, the anterolateral margin is divided into four lobes, the front bilobed, and the merus of the chelipeds and walking legs dorsally keeled. Ng (1983) included the genus in the Pilumnidae because the male first pleopod is slender and sinuous. Dentoxanthus has also the pulley-like dactylopropodal articulation characteristic of many pilumnids. However, the differences between this genus and the eumedonine genera are conspicuous. These include the characteristically sculptured carapace of Dentoxanthus, its strongly keeled and lamellate walking legs, and particularly the much expanded chelipeds similar to those seen in Calappa, and the tip of the male first pleopod is strongly hooked in contrast to the slightly-hooked pleopod of eumedonines. These differences strongly suggest that Dentoxanthus may not be a eumedonine but that it occupies an isolated position within the Pilumnidae (Števčić and $\mathrm{Ng}$, in preparation).

Although Rhabdonotus was initially included in the Xanthidae (Milne Edwards, 1879), Serène and Romimohtarto (1963) revised its systematic position and it $s$ now firmly established that it should be classified as a eumedonine inasmuch as it shares all principal eumedonine taxonomic features. It is a symbiont of crinoids and soft corals. 
It lacks, however, a marked junction between the anterolateral and posterolateral borders, so that the side margins of the carapace are more or less rounded.

It can be concluded, based on all available evidence, that Eumedonus and allied genera certainly differ from the parthenopids in adult morphology, as well as in ecological and larval (at least in Echinoecus) features. A close affinity to the Pilumnidae (sensu Guinot, 1978) is also evident but the peculiar mode of life of eumedonines emphasizes their status as an indepent taxon as suggested by the superfamily rank recently given to the group by Guinot (1985). The strong xanthoidean affinities discussed above, however, do not justify this elevation to superfamily level. We thus believe that the group should be elevated instead to family rank by re-establishing the family Eumedonidae Dana, 1853 within the superfamily Xanthoidea (sensu Guinot, 1978).

\section{Description of the Family}

\section{Family EUMEDONIDAE Dana, 1853}

Eumedonoidea Guinot, 1853, p. 453.

Eumedonidae Dana, 1853, p. 1422; Ortmann, 1893, p.419; 1894, p.48; Estampador, 1937, p. $559 ; 1959$, p. 120.

Eumedoninae Neuman, 1878, p. 17; Miers, 1879b, p.670; Haswell, 1882, p. 38; Miers, 1886, p. 104; Alcock, 1895, p. 258, 286; Klunzinger, 1906, p. 56; Borradaile, 1907, p. 481 (key); Rathbun, 1910, p. 321; 1918, p. 27; Balss, 1922, p. 136; Rathbun, 1925, p. 10 (key); Flipse, 1930, p. 18, 20, 70; Sakai, 1932, p. 300; Gordon, 1934, p. 62; Ward, 1934, p. 7; 1936, p. 10; Sakai, 1938a, p. 329, 347; Buitendijk, 1939, p. 266; Ward, 1942, p. 77; Stephensen, 1945, p. 114; Gordon, 1947, p. 111; Lin, 1949, p. 17; Edmondson, 1951, p. 217; Holthuis, 1953, p. 6; Balss, 1957, p. 1631; Serène et al., 1958, p. 136; Serène and Romimohtarto, 1963, p. 1; Sakai, 1965, p. 93 (key), 101; Serène, 1965, p. 21; 1968, p. 63; Glaessner, 1969, p. R508; Lundoer, 1974, p. 5; Suzuki and Takeda, 1974, p. 289; Sakai, 1976, p. 294; Serène, 1977, p. 49; Tirmizi and Kazmi, 1982, p. 308; Ng, 1983, p. 141; Kim and Chang, 1985, p. 50; Ng and Rodríguez, 1986, p. 90.

The family can be described as follows: Cephalothorax subpentagonal or subhexagonal, junction between anterolateral and posterolateral margins of carapace almost always well marked, usually having a spine. Projecting pseudorostrum bilobed or fourlobed, rarely emarginate. Surface of carapace nearly flat, sometimes bearing pointed tubercules, with more or less indistinctly marked regions. Circular orbits well defined but small; floor of orbits not in contact with the front, but leaving a hiatus, usually filled by basal $(2+3)$ antennal article and, in some genera, by the subsequent article. Antennae small, with small, discoidal first (urinal) article; basal antennal article the largest; two following articles smaller, provided with short flagellum. Epistome wide, short; buccal cavity quadrangular, completely covered by third maxillipeds; palp of third maxilliped well-developed, articulated at anterolateral angle of merus; exopod terminating in the flagellum. Chelipeds of moderate size, subequal, and in some genera longer than the carapace; fingers much shorter than palms, bent at an angle toward fixed finger; ischium and merus fused, but suture remaining very distinct and complete. Walking legs of moderate size, with coxae of last pair somewhat elevated over others; chelipeds and walking legs often armed with spines or cusps; dactyls can be flexed against the propodus producing a prehensile effect. Sternoabdominal cavity present; sternites arranged in parallel except last which is arranged radially; sternum with normal breadth; first two sternal sutures (4/5 and 5/6) interrupted; last two (6/7 and 738 ) complete [thus belanging to level III B according to Guinot (1979)]; a median line is present at 8 th sternite; a functional abdominal-retaining mechanism present. Male 
sexual opening coxal; the female sexual opening sternal, concave; first male gonopod long, slender, curved at middle, hooked apically; second gonopod distinctly shorter and sigmoid. Abdomen with seven non-fused segments in both sexes, the first one or two usually visible from above.

Members of the family are usually small (mostly around $1 \mathrm{~cm}$ in carapace length), typically concealed within their hosts (mostly echinoderms) and therefore rarely observed, collected, and studied. Fossils are unknown.

\section{Type genus: Eumedonus A. Milne Edwards, 1834}

The nine genera and 26 species of eumedonid crabs (see Table 1) can be classified according to the shape of the frontal and anterolateral margins of the carapace, the length of the walking legs and chelipeds, the surface of the carapace, the breadth of the inner orbital hiatus, the relative position of antennae (especially of the basal antennal segment), colouration, and type of hosts. The genera were grouped by some authors (Gordon, 1934; Serène et al., 1958) in two groups, A and B. Flipse (1930) and Sakai (1976) also used 'A' and ' $B$ ' in their keys but without any reference to groups.

\section{Subfamily Eumedoninae Dana, 1853}

Group A Gordon, 1934, p. 62; Serène et al., 1958, p. 138.

Carapace subpentagonal or subhexagonal. Prominent pseudorostrum consists of two median lobes or spines which are more or less divided by median notch or sinus. Distance between orbits at most half total width of carapace. Antennules folded slightly obliquely (almost longitudinally) into their fossae. Antennae rather short; basal article does not reach frontal margin, and together with subsequent articles, it usually fills orbital hiatus. Last two antennal segments (4 and 5) short. In some genera a ridge is present on inner side of shallow antennal groove. Eyes located at indentations formed by junction of anterolateral and frontal margins and are sometimes concealed by margins of carapace. Inner orbital margin not prominent. Anterolateral margin of carapace usually without teeth or lobes. Third pair of maxillipeds completely covers buccal cavity. Longitudinal endostomial ridges feebly marked. Chelipeds of moderate size and equal. Pereopods often have spines. All four walking legs have dactyls that are similar and subequal. The subfamily contains the genera Echinoecus Rathbun, 1894; Eumedonus H. Milne Edwards, 1834 (type); Gonatonotus White, 1847; Proechinoecus Ward, 1934; Rhabdonotus A. Milne Edwards, 1879; and Zebrida White, 1847.

\section{Ceratocarcininae new subfamily}

Group B Gordon, 1934, p. 62; Serène et al., 1958, p. 138.

Carapace almost subhexagonal. Fronto-orbital margin wide, exceeding by half the total width of carapace. Pseudorostrum consists of four parts: two median lobes (lamellate and curved downwards in some species) and two lateral lobes or spines projecting forward. Pseudorostrum also has frontal median notch plus two lateral grooves enclosing antennae. Eyes are situated laterally behind external lobes or spines. Inner suborbital angle prominent and well developed. Antennules fold obliquely (more transversely) into their fossae. Antennae moderate in size; basal article narrow, short, and does not (or barely) reach border of inner suborbital angle; next antennal articles usually long and narrow, fourth article fills orbital hiatus, and fifth, together with flagellum, lie in frontal grooves. In rare cases antennae are excluded from the very narrow orbital hiatus. Anterolateral margin of carapace has teeth or lobes. Third pair 
of maxillipeds does not completely cover buccal cavity. Longitudinal endostomial ridges well defined. Chelipeds very long and subcylindrical, with merus projecting well beyond margin of carapace; tips of fingers, usually light coloured, are dark only in a few rare species. First pair of walking legs has a slender dactylus and is much longer than following pairs. The latter are slender and subcylindrical. Most species have been reported from crinoids but one is known from a soft coral. In addition to the type genus, Ceratocarcinus White, 1847, the subfamily consists of the genus Harrovia Adams and White, 1848 and possibly Glyptocarcinus Takeda, 1973. The latter differs from Ceratocacinus and Harrovia in several morphological characters (see Takeda, 1979) and it has been collected as free-living.

\section{Acknowledgments}

The authors wish to thank Dr John S. Garth (Allan Hancock Foundation, University of Southern California, Los Angeles), Dr Danièle Guinot (Muséum national d'Histoire naturelle, Paris), Mr Peter K. L. Ng (Department of Zoology, National University of Singapore), and Dr Debbie L. Zmarzly (Point Loma Biology Laboratory, San Diego, California), for reviewing various versions of the manuscript. Mr P. Ng also provided invaluable information as well as some references difficult to obtain. P. Castro wishes to thank curators and staff members who facilitated his work at the Australian Museum, Sydney; British Museum (Natural History), London; Bernice P. Bishop Museum, Honolulu, Hawaii; Rijskmuseum van Natuurlijke Historie, Leiden, The Netherlands, and Muséum national d'Histoire naturelle, Paris. Ms Janet Haig and Ms Suzanne Henderson (Allan Hancock Foundation, University of Southern California) provided expert assistance in literature research. Z. Števčić thanks the Self-Management Community for Scientific Work of SR Croatia, Zagreb for financial support.

\section{References}

AdAMS, A and White, A., 1848, Crustacea. In: The Zoology of the Voyage of the H.M.S. Samarang; Under the Command of Captain Sir Edward Belcher, C.B., F.R.A.S., F.G.S. During the Years 1843-1846 (A. Adams, editor). Reeve, Benham, and Reeve, London, p. i-viii, 1-66, pl. 1-13.

Alcock, A., 1895, Materials for a carcinological fauna of India. No. 1. The Brachyura Oxyrhyncha. Journal of the Asiatic Society of Bengal 64, pt. II, no. 2, 157-291, pl. 3-5.

Anonymous, 1974, On zoological surveys of the South China Sea. Acta Zoologica Sinica 20, $113-130$.

Balss, H., 1921, Diagnosen neuer Decapoden aus den Sammlungen der Deutschen TiefseeExpedition und der japanischen Ausbeute Dofleins und Haberers. Zoologische Anzeiger 52, $175-178$.

BaLSS, H., 1922, Ostasiatische Decapoden. III. Die Dromiacen, Oxystomen und Parthenopiden.

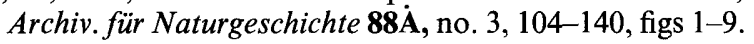

Balss, H., 1924, Decapoden des Roten Meeres III. Die Parthenopiden, Cyclo-und Catometopen. Expedition S. M. Schiff 'Pola' in des Rote Meer.Nördliche und Südliche Hälfte, 1895/961897/98. Zoologische Ergebnisse XXXIV. Denkschriften der Akademie der Wissenschaften in Wien: Mathematisch-Naturwissenschaftliche Klasse 99, 1-18, fig. 1.

Balss, H., 1938, Die Dekapoda Brachyura. In: Von Dr Sixten Bocks Pazifik-Expedition, 1917-1918. Göteborgs Kungl. Vetenskaps-och Vitterhets-Samhälles Handlingar, ser. B, 5, no. $7,1-85$, figs $1-18$, pl. 1-2.

Balss, H., 1957, Decapoda, Systematik. In: Dr. H. G. Bronns Klassen und Ordnungen des Tierreichs. Akademische Verlsgesellschaft, Leipzig, Band 5, Abteilung I 7, no. 12,

2 1505-1672, figs 1131-1199.

BARNARD, K. H., 1954, Notes sur une collection de crustacés décapodes de la région malagache. Mémoires de l'Institute Scientifique de Madagascar, sér A 9, 95-104. 
Borradaile, L. A., 1907, On the Classification of the Decapod Crustaceans. The Annals and Magazine of Natural History, ser 7 19, 457-486.

Bouvier, E. L. and Seurat, G., 1905, Eumedon convictor, crabe commensal d'un oursin. Comptes Rendus Hebdomadaires des Séances de l'Academie des Sciences, Paris 140, 629-631.

ButtendiJk, A. M., 1939, Biological Results of the Snellius Expedition. V. The Dromiacea, Oxystomata, and Oxyrhyncha of the Snellius Expedition. Temminckia 4, 223-276, pl. $7-11$.

ButTENDIJK, A. M., 1950, On a small collection of Decapoda Brachyura, chiefly Dromiidae and Oxyrhyncha, from the neighbourhood of Singapore. Bulletin of the Raffles Museum, Singapore, no. 21, 59-82.

Castro, P., 1971, Nutritional aspects of the symbiosis between Echinoecus pentagonus and its host in Hawaii, Echinothrix calamaris. In: Aspects of the Biology of Symbiosis (T. C. Cheng, editor). University Park Press, Baltimore, p. 229-247, figs 1-6, tables 1-5.

Castro, P., 1978, Settlement and habitat selection in the larvae of Echinoecus pentagonus (A. Milne Edwards), a brachyuran crab symbiotic with sea urchins. Journal of Experimental Marine Biology and Ecology 34, no. 3, 259-270, figs 1, tables 1-3.

Castro, P., 1986, Symbiosis in coral reef communities: a review. In: Coral Reef Population Biology (P. L. Jokiel, R. H. Richmond, and R. A. Rogers, editors). Hawaii Institute of Marine Biology Technical Report, no. 37, 292-307, table 1.

CAStro, P., in press, Range extensions and new host records of eumedonid crabs of the genus Harrovia Adams and White (Crustacea: Brachyura: Eumedonidae). Crustaceana.

DanA, J. D., 1853, Crustacea. In: United States Exploring Expedition, during the Years 1838, $1839,1840,1841,1842$, Under the Command of Charles Wilkes, U.S.N. C. Sherman, Philadelphia 13, pt. 2, 686-1618. Atlas (1855) 14, 1-27, pl. 1-96.

Daniel, A. and Krishnan, S., 1979, A parthenopid crab, Zebrida adamsii White, 1847 inhabiting interspaces of spines of the sea urchin, Salmacis virgulata L. Agaasiz, 1846. Bulletin of the Zoological Survey of India 1, no. 2, 171-175, pl. 4, table 1.

Edmondson, C. H., 1951, Some Central Pacific Crustaceans. Occasional Papers of the Bernice Pauahi Bishop Museum, Honolulu 20, no. 13, 183-243, figs 1-38.

ESTAMPADOR, E. P., 1937, A check list of Philippine crustacean decapods. The Philippine Journal of Science 62, 465-559.

EstampadoR, E. P., 1959, Revised check list of Philippine crustacean decapods. Natural and Applied Science Bulletin, University of the Philippines, Quezon City 17, no. 1, 1-127.

Fishelson, L., 1974, Ecology of the northern Red Sea crinoids and their epi- and endozoic fauna. Marine Biology 26, no. 2, 183-192, figs 1-8.

FliPSE, H. J., 1930, Die Decapoda Brachyura der Siboga-Expedition. VI Oxyrhyncha: Parthenopidae. Siboga Expeditie 39c ${ }^{2}$, livre 112, 1-96, figs 1-45.

GaRTH, J. S., 1964, The Crustacea Decapoda (Brachyura and Anomura) of Eniwetok Atoll, Marshall Islands, with special reference to the obligate commensals of branching corals. Micronesica 1, 1337-144, figs 1-2.

Glaessner, M. F., 1969, Decapoda. In: Treatise on Invertebrate Paleontology. Part $R$. Arthropoda 4, volume 2 (R. C. Moore, editor). Geological Society of America, Boulder, Colorado, p. R399-R533, R626-R628, figs 217-340.

Gordon, I., 1934, Crustacea Brachyura. In: Résultats Scientifiques du Voyage aux Indes Orientales Néerlandaises de le Prince et la Princesse Léopold de Belgique. Mémoires du Musée Royal d'Histoire Naturelle de Belgique, Bruxelles, hors. sér. 3, fasc. 15, 1-78, figs $1-37$.

GoRdon, I., 1947, Description of a new species of crab from Macclesfield Bank (Parthenopidae, Eumedoninae). Proceedings of the Linnean Society of London 159, no. 2, 111-113, fig. 1.

GoRe, R. H. and Scotto, L. E., 1979, Crabs of the family Parthenopidae (Crustacea Brachyura: Oxyrhyncha) with notes on specimens from the Indian River region of Florida. Memoires of the Hourglass Cruises 3, no. 4, 1-98, figs 1-34, 2 appendix figs.

Gravier, C., 1922, Sur un noveau crabe (Eumedonus petiti nov. sp.) commensal d'un oursin de Tulear (Madagascar). Bulletin du Muséum national d'Histoire naturelle, Paris 28, 484-486.

GrIFFIN, D. J. G., 1972, Brachyura collected by Danish expeditions in south-eastern Australia (Crustacea, Decapoda). Steenstrupia 2, no. 5, 49-90, figs 1-3.

GrifFIN, D. J. G. and YALDWIN, J. C., 1968, The constitution, distribution and relationships of 
the Australian Decapod Crustacea. A preliminary review. Proceedings of the Linnean Society of New South Wales 93, pt. 1, 164-183, figs 1-5, tables 1-6.

Guinot, D., 1964, Sur une collection de Crustacés Décapodes Brachyoures de Mer Rouge et de Somalie. Bolletino del Museo di Storia Naturale di Venezia 15, 7-63, figs 1-39, plates 1-4.

Guinot, D., 1978, Principes d'une classification évolutive des Crustacés Décapodes Brachyoures. Bulletin Biologique de la France et de la Belgique, n.s. 112, no. 3, 211-292, figs $1-3$, table 1 .

Guinot, D., 1979, Données nouvelles sur la morphologie, la phylogenèse et la taxonomie des Crustacés Décapodes Brachyoures. Mémoires du Muséum national d'Histoire naturelle, Paris, nouv. sér., sér A. Zool. 112, 1-354, figs 1-70, pl. 1-27.

Guinot, D., 1985, Crustacea. In: Fauna and Flora, A First Compendium of French Polynesian Sea-Dwellers (G. Richard, editor). Fifth International Coral Reef Congress. 1, 446-455.

Hale, H. M., 1927, The Crustaceans of South Australia. Part I. Harrison Weir, Adelaide, p. 1-210, figs 1-202.

Haswell, W. A., 1880, On the Australian Brachyura Oxyrhyncha. Proceedings of the Linnean Society of New South Wales 4, 431-458, pl. 25-27.

Haswell, W. A., 1882, Catalogue of the Austratian stalk- and sessile-eyed Crustacea. The Australian Museum, Sydney, p. iii-xxiv, 1-324, figs 1-8, pl. 1-4.

Henderson, J. R., 1893, A contribution to Indian Carcinology. Transactions of the Linnean Society of London, Zoology, ser. 2 5, 325-458, pl. 36-40.

Holthuis, L. B., 1953, Enumeration of the Decapod and Stomatopod Crustacea from Pacific coral islands. Atoll Research Bulletin 24, 1-66, maps 1-2.

Imanaka, T., Sasada, Y., Suzuki, H., Segawa, S. and Masuda, T., 1984, Crustacean decapod fauna in Kominato and adjacent waters Middle Honshu: a provisional list. Journal of the Tokyo University of Fisheries 71, no. 1, 45-74, figs 1-4, tables 1-2.

Johnson, D. S., 1962, Commensalism and semi-parasitism amongst decapod Crustacea in Singapore waters. In: The Proceedings of the First Regional Symposium on Scientific Knowledge of Tropical Parasites. University of Singapore, p. 282-288.

JoNes, S. and SANKARANKuTTY, C., 1961, Notes on animal association. 3. A parthenopid crab, Harrovia albolineata Adams \& White on a marimetrid crinoid, Lamprometre sp. Journal of the Marine Biological Association of India 2, no. 2, 194-196, fig. 1.

KIM, H. S., 1970, A Checklist of the Anomura and Brachyura (Crustacea, Decapoda) of Korea. Seoul National University Journal, Biology and Agriculture Series (B) 21, 1-34, fig. 1, pl. $1-5$.

KIM, H. S. and Chang, C. Y., 1985, The Brachyuran Crabs of Cheju Island, Korea (Crustacea: Decapoda). The Korean Journal of Systematic Zoology 1, nos. 1-2, 41-60, figs 1-4.

KLunZINGER, C. B., 1906, Die Spitz- und Spitzmund Krabben (Oxyrhyncha und Oxystomata) des Roten, Meeres. F. Enke, Stuttgart, p. i-vii, 1-88, figs 1-13, pl. 1-2.

LANCHESTER, W. F., 1900, On a Collection of Crustaceans made at Singapore and Malacca. Part 1. Crustacea Brachyura. Proceedings of the Zoological Society of London, 1900, 719-770, pl. $44-47$.

LAURIE, R. D., 1906, Report on the Brachyura collected by Professor Herdman, at Ceylon, in 1902. In: Report to the Government of Ceylon on the Pearl Oyster Fisheries of the Gulf of Manaar (W. A. Herdman, editor). Part 5, no. 40, p. 349-432, figs 1-12, pl. 1-2.

LENZ, H., 1905, Ostafrikanische Dekapoden und Stomatopoden, Gesammelt von Herrn Prof Dr. A. Voeltzkow. Abhandlungen Senckenbergische Naturforschende Gesellschaft, Frankfurt am Main 27, no. 4, 341-392, pl. 47-48.

LIN, C. C., 1949, A Catalogue of Brachyurous Crustacea of Taiwan. Quarterly Journal of the Taiwan Museum 2, no. 1, 10-33.

LUNDOER, S., 1974, A checklist of the marine Brachyura in the reference collection at PMBC, Thailand. Research Bulletin, Phuket Marine Biological Center, no. 4, 3-11.

MacCulloch, A. R., 1913, Studies in Australian Crustacea. No. 3. Records of the Australian Museum 9, 321-353, figs 42-53, pl. 10-11.

MACGilchrist, A. C., 1905, Natural History Notes from the R.I.M.S. 'Investigator', Capt. T. H. Heming, R.N. (retired), commanding. Ser. III, No. 6. An account of the new and some

- of the rarer Decapoda Crustacea obtained during the surveying seasons 1901-1904. The Annals and Magazine of Natural History, ser. 7 15, 233-268.

MaN, J. G., DE, 1887, Report on the Podophthalmous Crustacea of the Mergui Archipelago, collected for the Trustees of the Indian Museum, Calcutta, by Dr John Anderson, F.R.S., 
Superintendent of the Museum. Part I-V. Journal of the Linnean Society of London, Zoology, 22, 1887, nos. 136-137, 1-128; 22, 1888, nos. 138-140, 129-312, pl. 1-19.

MAN, J. G., DE, 1888, Bericht über die im indischen Archipel von Herrn Dr. J. Brock gesammelten Decapoden und Stomapoden. Archiv für Naturgesichte, Berlin 53, no. 1, 215-600, pl. 7-22a.

MAN, J. G., DE, 1902, Die von Herrn Professor Kükenthal im Indischen Archipel gesammelten Dekapoden und Stomatopoden. Ergebnisse einer zoologischen Forschungsreise in den Molukken und Borneo, im Auftrage der Senckenbergischen naturforschenden Gesellschaft ausgeführt von Dr. Willy Kükenthal. Abhandlungen Senckenbergische Naturforschende Gesellschaft, Frankfurt am main 25, no. 3, 467-929, pl. 19-27.

MCNeill, F. A., 1968, Crustacea, Decapoda \& Stomatopoda. In: Great Barrier Reef Expedition 1928-29. Scientific Reports of the Great Barrier Reef Expedition 7, no. 1, 3-98, pl. 1-2.

Miers, E. J., 1879a, Descriptions of new or little-known species of Maioid Crustacea (Oxyrhyncha) in the collection of the British Museum. The Annals and Magazine of Natural History, ser. 54, 1-28, pl. 4-5.

Miers E. J., 1879b, On the Classification of the Maioid Crustacea or Oxyrhyncha, with a Synopsis of the Families, Sub-families, and Genera. Journal of the Linnean Society of London, Zoology 14, 634-673, pl. 12-13.

MIERS, E. J., 1879c, On a Collection of Crustacea made by Capt. H. C. St. John, R.N., in the Corean and Japanese Seas. Part I. Podophthalmia, With an Appendix by Capt. H. C. St. John. Proceedings of the Zoological Society of London, 1879, 18-60, pl. 1-3.

MiERS, E. J., 1886, Report on the Brachyura collected by H.M.S. 'Challenger' during the Years 1873-76. In: Report of the Scientific Results of the Voyage of H.M.S. 'Challenger', Zoology. Part 49, vol. 17, p. i-L, 1-362, pl. 1-29.

Milne EdwARDS, A., 1872, Recherches sur la faune carcinologique de la Nouvelle Calédonie. I. Groupe des Oxyrhinques. Nouvelles Archives du Muséum national d'Histoire naturelle, Paris 8, 229-267, pl. 10-14

Milne Edwards, A., 1879, Description de quelques Crustacés nouveaux. Bulletin de la Société Philomatique de Paris, ser. 7 3, 103-110.

Milne Edwards, H., 1834, Histoire Naturelle des Crustacés, Comprenant l'Anatomie, la Physiologie et la Classification des ces Animaux. Librairie Encyclopédique de Roret, Paris, Vol. 1, p. i-Xxxv, 1-468. Atlas, pages 1-32, pl. 1-42.

MiYaKe, S., 1939, Note on crabs of the genus Echinoecus Rathbun living commensally with Echinoids (Parthenopidae, Eumedoninae). Annotationes zoologicae japonenses, Tokyo 18, no. 2, 83-94, figs $1-3$.

Monod, T., 1938, Decapoda Brachyura. VIII. In: Mission Robert Ph. Dollfus en Égypt. Mémoires de l'Institut d'Égypte 37, 91-162, figs 1-29.

Morrison, J. P. E., 1954, Ecological Notes on the Mollusks and Other Animals of Raroia. Atoll Research Bulletin 34, 1-18.

Mortensen, T., 1943, A Monograph of the Echinoidea. III. 2 Camarodonta. I. Orthopsidae, Glyphocyphidae, Temnopleuridae and Toxopneustidae. C. A. Reitzel, Copenhagen, p. 1-553, figs 1-321, pl. 1-56.

Natyanetr, P., 1980, Crustacean fauna of Thailand (Decapoda and Stomatopoda). Department of Biology, Faculty of Science, Chulalangkorn University, Bangkok, p. 1-73.

NeumanN, R., 1878, Systematische Uebericht der Gattungen der Oxyrhynchen: Catalog der podophthalmen Crustaceen des Heidelberger Museums. Beschreibung Eineger Neuer Arten. J. B. Hirschfeld, Leipzig, p. 1-39.

NG, P. K. L., 1983, Aspects of the systematics of the Family Pilumnidae Samouelle, 1819 (Crustacea, Decapoda, Brachyura) and a study on evolutionary trends within the superfamily Xanthoidea (sensu Guinot 1978). Unpublished B.Sc.(Honours) Thesis. National University of Singapore, p. i-viii, 1-251, figs 1-53, pl. 1-12.

NG, P. K. L. and RodrígueZ, G., 1986. New records of Mimilambrus wileyi Williams, 1979, (Crustacea: Decapoda: Brachyura), with notes on the systematics of the Mimilambridae Williams, 1979, and Parthenopidae Macleay, 1838, sensu Guinot, 1978. Proceedings of the Biological Society of Washington 99, no. 1, 88-99, fig. 1-4, table 1.

NoBILI, G., 1907, Ricerche sui Crostacei della Polinesia. Decapodi, Stomatopodi, Anisopodi e Isopodi. Memorie dell' Accademia delle Scienze di Torino, ser. 2, 57, 351-430, pl. 1-3.

OoIsHI, S., 1970, Marine invertebrates fauna of the Ogasawara and Volcano Islands collected by 
S. Ooishi, Y. Tomida, K. Izawa and S. Manabe. In: Report on the Marine Biological Expedition to the Ogasawara (Bonin) Islands, 1968, Asahi Shimbun Publ., Tokyo, p. 75-104, pl. 1-25.

Ortmann, A., 1893, Die Decapoden-Krebse des Strassburger Museums, VII. Brachyura I, Gruppe: Cyclometopa. Zoologische Jahrbucher, Jena, Abtheil für Systematik 7, no. 3, 411-495, pl. 17.

Ortmann, A., 1894, Crustaceen. In : R. Semon, Zoologische Forschungsreisen in Australien und dem Malayischen Archipel. Denkschriften der Medicinish-Naturwissenschftlichen Gesellschaft zu Jena 8, 1-80, pl. 1-3 (in Atlas).

RathbuN, M. J., 1894, Notes on the crabs of the family Inachidae in the United States National Museum. Proceedings of the United States National Museum 17, 43-75, pl. 1.

Rathbun, M. J., 1906, The Brachyura and Macrura of the Hawaiian Islands. Bulletin of the United States Fish Commission 23, pt. 3, i-viii, 827-930, figs 1-79, pl. 3-24.

Rathbun, M. J., 1910, Brachyura, V. In: The Danish Expedition to Siam 1899-1900. K. Danske Videnskabernes Selskabs Skrifter, Copenhagen, ser. 7 4, 303-367, figs 1-44, pl. 1-2, map.

Rathbun, M. J., 1911, Marine Brachyura. In: The Percy Sladen Trust Expedition to the Indian Ocean in 1905, under the leadership of Mr J. Stanley Gardiner. Vol. III. No. XI. Transactions of the Linnean Society of London, Zoology, ser. 2, 14, part 2, 191-261, pl. 15-20.

Rathbun, M. J., 1918, Report on Spider Crabs. In: Report on the Crabs obtained by the F. I. S. 'Endeavour' on the Coasts of Queensland, New South Wales, Victoria, South Australia and Tasmania. Biological Results of the Fishing Experiments Carried on by the F.I.S. 'Endeavour' 1909-14, Sydney 5, pt. 1, 1-29, figs 1-3, pl. 1-14.

Rathbun, M. J., 1925, The spider crabs of America. Bulletin of the United States National Museum 129, i-xx, 1-598, figs 1-153, pl. 1-283.

Roxas, H. A., 1930, The Puerto Galera Marine Biological Laboratory of the University of the Philippines (A Report to the President of the University, together with a check-list of animals of the Puerto Galera Region). University of the Philippines, Manila, p. 1-24, pl. $1-4$.

SAKAI, T., 1932, Brachyura from the coast of Kyushu, Japan. Science Reports of the Tokyo Bunrika Daigaku, sect. B 1, no. 25, 281-330, figs 1-26, pl. 17-18.

SAKAI, T., 1938a, Studies on the Crabs of Japan. III. Brachygnatha, Oxyrhyncha. Yokendo, Tokyo, p. 193-364, text figs 1-55, pl. 20-41.

SAKAI, T., 1938b, Brachyura obtained from Ôsima, province Kii. Annotationes zoologicae japonenses, Tokyo 17, no. 4, 43-57, figs 1-2.

SAKAI, T., 1939, Studies on the Crabs of Japan. IV. Brachygnatha, Brachyrhyncha. Yokendo, Tokyo, p. 365-741, text figs 1-129, pl. 42-111, table 1 .

SAKAI, T., 1965, The Crabs of Sagami Bay Collected by His Majesty the Emperor of Japan. Maruzen Co., Tokyo, p. i-xvi, 1-206 (in English), 1-92 (in Japanese), 1-32 (bibliography and index), text figs 1-27, pl. 1-100, 1 map.

SaKaI, T., 1974, Notes from the carcinological fauna of Japan (V). Researches on Crustacea, Carcinological Society of Japan, no. 6, 86-102, frontispiece fig. 1.

SAKAI, T., 1976, Crabs of Japan and the Adjacent Seas. Kodansha, Ltd., Tokyo, p. i-xxix, 1-733, text figs 1-379, maps 1-3 (in English); 1-461, text figs 1-2 (in Japanese); pl. 1-251 (Plates volume).

SANDIFER, P. A., 1974, Larval stages of the crab, Pilumnus dasypodus Kingsley (Crustacea, Brachyura, Xanthidae), obtained in the laboratory. Bulletin of Marine Science 24, no. 2, 378-391, figs 1-6.

SankarankutTy, C., 1966, On Decapoda Brachyura from the Gulf of Mannar and Polk Bay. Proceedings of the Symposium on Crustacea, Marine Biological Association of India, part 1, 347-367, figs 1-33, pl. 1-2.

SASTRY, D. R. K., 1977, On some crustacean association of sea-urchins of the Andaman and Nicobar Islands. Newsletter of the Zoological Survey of India 3, no. 3, 119-120.

SASTRY, D. R. K., 1981, On some crustacean associates of Echinodermata from the Bay of Bengal. Records of the Zoological Survey of India 79, 19-30, figs 1-4, pl. 1.

${ }_{2}$ SERÈnE, R., 1961, A note on the systematics of the Brachyura and the morphology of commensual species. Proceedings of the Ninth Pacific Science Congress, Bangkok 10, 32-34. 
SERÈNE, R., 1965, Guide for curators of brachyuran collections in Southeast Asia. Applied Scientific Research Corporation of Thailand, Bangkok, p. 1-65.

SerÈnE, R., 1968, The Brachyura of the Indo-West Pacific region. In: Prodromus for a Check List of the non-planctonic Marine Fauna of South East Asia, Singapore Academy of Sciences, Special Publication no. 1, 33-112.

SERÈnE, R., 1977, Crustacés Hippidés et Brachyoures des îles Séchelles. (1 re partie). Revue de Zoologie Africaine 91, no. 1, figs 1-38.

Serène, R., Duc, T. V. and Luom, N. V., 1958, Eumendoninae du Viet-Nam (Crustacea) (avec un Bibliographie de la Sous-famille). Treubia 24, no. 2, 135-242, figs 1-14, pl. 4-7.

Serène, R. and RommohtaRto, K., 1963, On some species of Eumendoninae from IndoMalayan region. Marine Research in Indonesia 6, 1-6, figs 1-5, pl. 1-2.

Serène, R., Romimohtarto, K. and Moosa, M. K., 1974, The Hippidea and Brachyura collected by the Rumphius Expedition I. In: Report on the Rumphius Expedition I (January 6-February 1, 1973). Oseanologi di Indonesia, no. 1, 17-26.

SERENE, R. and VADON, C., 1981, Crustacés Décapodes: Brachyoures. Liste préliminaire, description de formes nouvelles et remarques taxonomiques. In: Résultats des Campagnes MUSORSTOM. I-Philippines (18-28 mars 1976), Tome 1. Mémoires ORSTOM (Office de la Recherche Scientifique et Technique Outre-Mer) 91, 117-140, pl. 1-4, figs 1-3.

Shen, C., DAI, A. and CHEN, H., 1982, New and rare species of Parthenopidae (Crustacea: Brachyura) from China Seas. Acta Taxonomica Sinica 7, no. 2, 139-151, figs 1-15, pl. 1-2.

STEPHENSEN, K., 1945, The Brachyura of the Iranian Gulf. With an Appendix: The Male Pleopoda of the Brachyura. In: Danish scientific Investigations in Iran, part IV. E. Munksgaard, Copenhagen, p. 57-237, figs. 1-60.

STIMPSON, W., 1857, Prodromus descriptionis animalium evertebratorum, quae in Expeditione ad Oceanum Pacificum Septentrionalem, a Republica Federata missa, Cadwaladaro Ringgold et Johanne Rodgers ducibus, observavit et descripsit W. Stimpson, Pars III. Crustacea Maioidea. Proceedings of the Academy of Natural Sciences of Phladelphia 9, 216-221.

SuzuKI, K. and TAKEDA, M., 1974, On a parthenopid crab, Zebrida adamsii on the sea urchins from Suruga Bay, with a special reference to their parasitic relations. Bulletin of the National Science Museum, Tokyo 17, no. 4, 287-296, figs 1-4, pl. 1.

TAKeda, M., 1973, A new genus and a new species of the Parthenopidae from the sea off the Ogasawara Islands (Crustacea, Brachyura). Bulletin of the National Science Museum, Tokyo 16, no. 1, 31-36, fig. 1.

TAKEDA, M., 1979, Generic and specific validity of Glyptocarcinus lophopus Takeda (Crustacea, Brachyura). Proceedings of the Japanese Society of Systematic Zoology 17, 68-72.

TAKEDA, M. and MryaKe, S., 1972, Crabs from the East China Sea, V. A remaining collection. OHMU, Occasional Papers of Zoological Laboratory, Faculty of Agriculture, Kyushu University, Fukuoka, Japan 3, no. 8, 63-90.

TiRmizi, N. M. and KAZMI, Q. B., 1982, Range extension of Harrovia elegans De Man, 1887, with a note on the male of Dentoxanthus iranicus Stephensen, 1945, from the Northern Arabian Sea (Decapoda, Brachyura, Eumedoninae). Crustaceana 43, no. 3, 308-313, figs 1-3.

TIRMIZI, N. M. and SerÈne, R., 1971, The rediscovery of two species of crabs (Decapoda, Brachyura) with observations on three other species from Pakistan. Crustaceana 21, no. 1, 21-32, figs 1-4, pl. 1-2.

TwEEDIE, M. W. F., 1950, The fauna of the Cocos-Keeling Islands, Brachyura and Stomatopoda. Bulletin of the Raffles Museum, Singapore, no. 22, 105-148, figs 1-4, pl. 16-17.

Van Dover, C. L., Gore, R. H. and Castro, P., 1986, Echinoecus pentagonus (A. Milne Edwards, 1879): larval development and systematic position (Crustacea: Brachyura: Xanthoidea nec Parthenopoidea). Journal of Crustacean Biology 6, no. 4, 757-776, figs $1-5$, tables 1-2.

WALKER, A. O., 1887, Notes on a Collection of Crustacea from Singapore. Journal of the Linnean Society of London, Zoology 20, 107-117, pl. 6-9.

WARD, M., 1934, Notes on a Collection of Crabs from Christmas Island, Indian Ocean. Bulletin of the Raffles Museum, Singapore, no. 9, 5-28, pl. 1-3.

WARD, M., 1936, Crustacea Brachyura from the coasts of Queensland. Memoires of the Queensland Museum 11, no. 1, 1-13, pl. 1-3. 
WARD, M., 1942, Notes on the Crustacea of the Desjardin Museum, Mauritius Institute, with description of new genera and species. The Mauritius Institute Bulletin 2, pt. 2, 49-108, plates 5-6.

White, A., 1847a, Descriptions of new Crustacea from the Eastern Seas. Proceedings of the Zoological Society of London, pt. 15, 56-58 (also in The Annals and Magazine of Natural History 20, 61-70).

WHITE, A., 1847b, Descriptions of new or little-known Crustacea in the collection of the British Museum. Proceedings of the Zoological Society of London, pt. 15, 118-126.

WHITE, A., 1847c, List of specimens of Crustacea in the collection of the British Museum, London. British Museum, London, p. 1-143.

Wicksten, M. K., 1983, Camouflage in marine invertebrates. Oceanography and Marine Biology, Annual Reviews 21, 177-193, figs 1-7, tables 1-2.

Zehntner, L., 1894, Crustacés de l'Archipel Malais. Voyage du MM. M. Bedot et C. Pictet dans l'Archipel Malais. Revue Suisse de Zoologie 2, 135-214, pl. 7-9. 